\title{
A ssessment of sustainable vermiconversion of water hyacinth by Eudrilus eugeniae and Eisenia fetida
}

\author{
N. K annadasan ${ }^{1}$, Nirmala Natarajann ${ }^{1}$, N. A nbusaravanan ${ }^{1 *}$, P. Sekar ${ }^{2}$ and R. K rishnamoorthy ${ }^{3}$
}

${ }^{1}$ Research Department of Zoology, Periyar E.V.R. College, Tiruchirappalli-620023, (Tamil Nadu), INDIA

${ }^{2}$ Research Department of Zoology, National College, Tiruchirappalli- 620021, (Tamil Nadu), INDIA

${ }^{3}$ Department of Biotechnology, Bharathidasan University, Tiruchirappalli- 620024, (Tamil Nadu), INDIA

*Corresponding author. E-mail: drnanbun@gmail.com

Received:February 13, 2013; Revised received:August 21, 2013; Accepted:O ctober 28, 2013

\begin{abstract}
The present work has assessed sustainable vermiconversion of aquatic weed water hyacinth (Eichornia crassipes). The garden soil, water hyacinth and cow dung were taken in the following the combinations of $1: 2: 1,2$ $: 1: 1$ and $1: 1: 2$. Two species of earthworms Eudrilus eugeniae and $E$ isenia fetida was used for the experiment. The total nitrogen $(0.18 \%$ in control and $1.68 \%$ in earthworm treated) and phosphate $(0.63 \%$ in control and $1.64 \%$ in earthworm treated) levels were increased and toxic heavy metals zinc (7.66 ppm in control and $2.58 \mathrm{ppm}$ in earthworm treated) and copper (6.68 ppm in control and $1.15 \mathrm{ppm}$ in earthworm treated) were significantly decreased. The earthworm enriches the compost with various nutrients for plant and microbial growth. Plant growth studies were conducted in all the combination of water hyacinth, maximum growth of root length $(8.9 \mathrm{~cm}$ and 7.2 in control) and shoot length $(21.6 \mathrm{~cm}$ and 16.2 in control) observed compare to control. Gut microbial analysis revealed that Bacillus cereus, Micrococcus luteus were predominantly present in the earthworm. The study recommended that the aquatic weed compost was suitable of agricultural usage.
\end{abstract}

Keywords: Earthworms, Eisenia fetida,Eudrilus eugeniae, Vermiconversion, Water hycinth

\section{INTRODUCTION}

Earthworms greatly influence soil properties and crop production, which result in the continuous turnover of the soil and mixing of minerals and organic constituents. Worms that live in the soil are the farmer's and gardener's friends. Vermicompost is also seven times richer than compost that has been rotted without introduction of worms, so only one seventh of the quantity is needed to enrich the soil. Tests in India have shown that vermin compost application can double wheat yields and quadruple yields of fodder (Edwards and Burrows, 1988). The vermicompost is produced from a cheap raw material (community wastes including farm wastes) which is in plenty all over the world. Vermicompost production is also an economically productive process as it reduces wastes at source and consequently saves landfills space (Sinha et al., 2008).

Vermicomposting is a self-promoted, self-regulated, selfimproved and self-enhanced, low or no-energy requiring zero-waste technology, easy to construct, operate and maintain. As vermicompost also helps the crops to attain maturity and reproduce faster, it shortens the harvesting time. The cost of production of vermicompost is simply insignificant as compared to chemical fertilizers. This further cuts on the cost of production and also adds to economy of farmers as they can grow more crops every year in the same farm plot (Gajalakshmi and Appasi, 2002). Aim of the present study to use earth worms to convert the aquatic weed Eichirnia waste into wealth by vermitechnology and find out suitable proportion for best plant growth.

\section{MATERIALS AND METHODS}

Collection and processing: In present study water hyacinth was utilized for composting. Two species of earthworms Eudrilus eugeniae and Eisenia fetida were bought from a vermiculture farm situated in Vallum, Tanjore ( $10^{\circ} 48^{\prime} 0{ }^{\prime \prime}$ North, $79^{\circ} 9^{\prime} 0$ " East), Tamil Nadu, India. The earthworms were reared in garden soil and garden waste vermibed of dimension $4 \times 2 \times 4 / 4$ feet (length $\times$ breadth $\times$ height) sufficient for 2,000 to 3,000 worms with controlled moisture $35-45 \%$ and temperature $26^{\circ} \mathrm{C}-28^{\circ} \mathrm{C}$. Cow dung (CD) produced from the Srinivasa Cowshed, Tiruchirapalli, India, served as feed. The main characteristics of CD were total solids, $562 \mathrm{~g} / \mathrm{kg}$; $\mathrm{pH}(1: 10$ ratio) 7.81; total organic carbon (TOC), $481 \mathrm{~g} / \mathrm{kg}$; total nitrogen (TN), $5.8 \mathrm{~g} / \mathrm{kg}$; total phosphorous (TP), $6.4 \mathrm{~g} / \mathrm{kg}$ and $\mathrm{C}: \mathrm{N}$ ratio, 82.93. Aquatic weed water hyacinth was collected from the pond located at Khajamalai.

Experimental setup: After an acclimatization period of 40 days the worms were selected for experiment. They were put in groups into earthen pots of $5 \mathrm{~kg}$ capacity. Seven pots were taken for the experiment. The posts were 
marked as $\mathrm{T}_{1}, \mathrm{~T}_{2}, \mathrm{~T}_{3}$, (E. eugeniae) $\mathrm{T}_{4}, \mathrm{~T}_{5}, \mathrm{~T}_{6}(\mathrm{E}$. fetida) for water hyacinth and control. Each earthen pot was having a small pore at the bottom to drain excess water. The garden soil, water hyacinth and cow dung were taken in the following combinations.

\begin{tabular}{cccccc}
\multicolumn{3}{c}{ Eichornia + Soil } & \multicolumn{3}{c}{ Cow dung $(\mathrm{E}: \mathrm{S}: \mathrm{C})$} \\
1 & $:$ & 2 & $:$ & 1 & $\left(\mathrm{~T}_{1}\right)$ \\
2 & $:$ & 1 & $:$ & 1 & $\left(\mathrm{~T}_{2}\right)$ \\
1 & $:$ & 1 & $:$ & 2 & $\left(\mathrm{~T}_{3}\right)$
\end{tabular}

Soil analysis: Soil samples collected horizon wise powdered with wooden mallet and passed through a 2 $\mathrm{mm}$ sieve and utilized for analysis. Soil samples analysis were done before and after the experiment by following standard methods. The $\mathrm{pH}$ was measured using $\mathrm{pH} 615$, digital $\mathrm{pH}$ meter in $1 / 10(\mathrm{w} / \mathrm{v})$ aqueous solution (Electronics India. Modle112). Total Organic Carbon (TOC) was determined by the partial-oxidation method (Walkley and Black, 1934), Total Nitrogen (TN) was measured by micro Kjeldahl method (Jackson 1975). C:N ratio was calculated from the measured value of $\mathrm{C}$ and $\mathrm{N}$. Total extractable Phosphorous (TP) was determined by using Olson's sodium bicarbonate extraction method (Olsen et al., 1954), K, Ca and Mg were determined after extraction of the sample using ammonium acetate extractable method (Simard et al., 1993) and the samples were analysed by Perkin Elmer AA-6300, double beam Atomic Absorption Spectrophotometer (AAS).

Plant growth study: Plants seedlings (Lady's finger Abel moschus esculentus) were planted in polythene bags containing vermicompost (capacity - $1 \mathrm{Kg}$ ). After 30 days, plant height (from soil level to the top node) and total leaf number (except cotyledon) of each plant were recorded. At the end of growth period, five plants from each treatment were harvested to measure length of the shoots and roots.

G ut analysis: The worms were washed with sterile water to remove the surface microbial flora from its outer skin. The earthworms were then sacrificed by freezing and their whole body was dissected. The midgut region approximately $(3-5 \mathrm{~cm})$ was taken for analysis and all plating works for bacteriological analysis were carried out immediately. One $\mathrm{g} / \mathrm{ml}$ of the sample was taken in sterilized test tube and serially diluted to obtain the pure culture. From the pure culture, samples were taken and screened with routine microbial screening procedure such as Gram staining, following biochemical tests.

\section{RESULTS AND DISCUSSION}

Water hyacinth is commonly found in India and it is a problematic weed in a large number of districts in India. It has choked hundreds of water bodies in India. Millions of Dollars are spent, on control of this menacing weed all over the world. Ecologically devastating properties of water hyacinth can be profitably used as compost after conversion by vermitechnology.

The $\mathrm{pH}$ of the control (6.94), inoculated with $\mathrm{E}$. eug eniae and $E$. fetida did not showed much variation $(6.85-6.94)$. But various combination of E:S:C, treated with $E$. eugeniae (7.84 -8.09) showed higher values than the same treated with $E$. fetida (7.92) (Table 1).

The Electrical conductivity (EC) of the control was 1.75 $\mathrm{dms}^{-1}-1.80 \mathrm{dms}^{-1}$. The EC of compost was improved from the control in all combination of water hyacinth treated with both species (1.87 to $\left.2.42 \mathrm{dms}^{-1}\right)$. Soil EC was an outstanding parameter in precision Agriculture. This reflects the spatial understanding of soil-water-plant relationship (Corwin and Lesch, 2003). This shows a good conversion of manure.

The percentage of organic carbon was reduced from control $(9.32 \%$ and $9.74 \%)$ in the water hyacinth treated with $E$. eugeniae ( $8.16 \%$ to $9.48 \%$ ), when compared to the same treated with $E$. fetida $(7.94 \%$ to $9.16 \%)$. But there was reduction in percentage of organic carbon, in the water hyacinth waste treated with both the species of earthworms. The percentage of organic matter increased from control $(10.16 \%-8.92 \%)$ in both the waste treated with both the species. The results showed the ability of both species in converting the waste into organic matter $(15.18 \%-18.96 \%)$ and also can exhibits the decomposing and mineralization of organic waste. The biological mutuality is suggested to cause TOC loss in the form of $\mathrm{CO}_{2}$ from the tannery sludge during the decomposition and mineralization of organic waste (Suthar, 2007)

The percentage of Total Nitrogen (TN) showed the increasing order in the water hyacinth treated with $E$. eugeniae and $E$. fetida $(0.18 \%-0.79 \%)$ in control and $(1.54 \% 1.98 \%)$ in water hyacinth waste. It is suggested that along with nitrogen release from compost material, earthworm enhanced nitrogen level by releasing mucus and by accumulating excretory products, body fluids and other biological fluids rich in nitrogen (Edwards and Burrows, 1988). Decaying tissues of dead worms is also one of the factors for TN increase in a significant amount. Gajalakshmi et al. (2001, 2002) and Gupta et al. (2007) observed the earthworm mortality during the water hyacinth vermicomposting.

The total phosphorus (TP) and total potassium (TK) increased in their respective percentages from control. The percentage levels of TK showed double fold increase when compared to TP. Both the species of earthworms exhibited comparatively better in converting the waste and increasing the percentage of NPK. Earthworms are very sensitive to ammonia and cannot survive organic waste containing high level of using cation (Dominguez, 2004).

Total Zinc was reduced from $7.66 \mathrm{ppm}$ in control and 2.98 $\mathrm{ppm}$ to $2.54 \mathrm{ppm}$ in water hyacinth treated with $\mathrm{E}$. 
Table 1. Analysis of macro and micro nutrients in the sample (water hyacinth) in various ratios inoculated with $E$. eugeniae and E. fetida.

\begin{tabular}{|c|c|c|c|c|c|c|c|c|c|}
\hline \multirow{2}{*}{$\begin{array}{l}\text { S. } \\
\text { No. }\end{array}$} & \multirow{2}{*}{$\begin{array}{l}\text { M acronutrients / } \\
\text { M icr onutrients }\end{array}$} & \multirow[b]{2}{*}{ Control } & \multicolumn{3}{|c|}{ E. eugeniae } & \multirow[b]{2}{*}{ Contr ol } & \multicolumn{3}{|c|}{ E . fetida } \\
\hline & & & $\begin{array}{c}\mathrm{E}+\mathrm{S}+\mathrm{C} \\
1: 2: 1\end{array}$ & $\begin{array}{c}\mathrm{E}+\mathrm{S}+\mathrm{C} \\
2: 1: 1\end{array}$ & $\begin{array}{c}\mathrm{E}+\mathrm{S}+\mathrm{C} \\
1: 1: 2\end{array}$ & & $\begin{array}{c}\mathrm{E}+\mathrm{S}+\mathrm{C} \\
1: 2: 1\end{array}$ & $\begin{array}{c}\mathrm{E}+\mathrm{S}+\mathrm{C} \\
2: 1: 1\end{array}$ & $\begin{array}{c}\mathrm{E}+\mathrm{S}+\mathrm{C} \\
1: 1: 2\end{array}$ \\
\hline$\overline{1}$ & $\mathrm{pH}$ & 6.94 & 7.84 & 8.05 & 7.84 & 6.85 & 7.89 & 8.07 & 8.14 \\
\hline 2 & $\mathrm{EC}\left(\mathrm{dms}^{-1}\right)$ & 1.75 & 1.87 & 1.90 & 2.42 & 1.80 & 1.88 & 1.95 & 2.14 \\
\hline 3 & Organic C (\%) & 9.32 & 9.48 & 8.19 & 8.16 & 9.74 & 8.26 & 9.16 & 7.94 \\
\hline 4 & Organic matter $(\%)$ & 10.16 & 18.96 & 16.38 & 16.32 & 8.92 & 16.52 & 18.32 & 15.88 \\
\hline 5 & Total N (\%) & 0.18 & 1.58 & 1.68 & 1.54 & 0.79 & 1.62 & 1.98 & 1.74 \\
\hline 6 & Total P(\%) & 0.63 & 1.54 & 1.64 & 1.48 & 0.55 & 1.42 & 1.46 & 1.42 \\
\hline 7 & Total K (\%) & 0.56 & 2.69 & 2.64 & 2.58 & 0.48 & 2.67 & 2.69 & 2.58 \\
\hline 8 & Total Zn (ppm) & 7.66 & 2.72 & 2.58 & 2.98 & 7.50 & 2.67 & 2.79 & 2.54 \\
\hline 9 & Total $\mathrm{Cu}(\mathrm{ppm})$ & 6.68 & 1.20 & 1.22 & 1.15 & 6.62 & 1.26 & 1.30 & 1.25 \\
\hline 10 & Total Fe (ppm) & 1.22 & 19.64 & 16.38 & 15.97 & 1.16 & 18.36 & 18.34 & 19.34 \\
\hline 11 & Total Mn (ppm) & 1.92 & 5.94 & 4.98 & 4.57 & 1.78 & 4.28 & 4.67 & 4.19 \\
\hline
\end{tabular}

E- Eichornia; S- soil; C-cow dung.

Table 2. Growth parameters of Abelmoschus esculentus using E ichornia compost.

\begin{tabular}{|c|c|c|c|c|c|}
\hline \multirow[b]{2}{*}{ S. No. } & \multirow[b]{2}{*}{ Concentration } & \multicolumn{2}{|c|}{ E. eugeniae } & \multicolumn{2}{|c|}{ E. fetida } \\
\hline & & $\begin{array}{l}\text { Root length } \\
(\mathrm{cm})\end{array}$ & $\begin{array}{l}\text { Shoot length } \\
(\mathrm{cm})\end{array}$ & $\begin{array}{l}\text { Root length } \\
(\mathrm{cm})\end{array}$ & $\begin{array}{c}\text { Shoot length } \\
(\mathrm{cm})\end{array}$ \\
\hline 1 & Control & 7.6 & 16.2 & 7.2 & 17.3 \\
\hline 2 & $\begin{array}{l}E+S+C \\
1: 2: 1\end{array}$ & 8.9 & 21.6 & 8.4 & 18.2 \\
\hline 3 & $\begin{array}{l}E+S+C \\
2: 1: 1\end{array}$ & 8.5 & 19.5 & 8.0 & 19.2 \\
\hline 4 & $\begin{array}{l}E+S+C \\
1: 1: 2\end{array}$ & 8.2 & 20.1 & 8.5 & 21.3 \\
\hline
\end{tabular}

E- Eichornia; S- soil; C-cow dung.

eugeniae, and the total $\mathrm{Cu}$ also shown similar trend (6.68 ppm in control and $1.30 \mathrm{ppm}$ to $1.15 \mathrm{ppm}$ in earthworm treated). The reduction of total carbon was also followed the same pattern. The percentage reduction was more in the water hyacinth among the samples treated with both species. The results showed the decrease in toxic compounds such as $\mathrm{Zn}$ and $\mathrm{Cu}$ in the treated waste reflecting the potential of both species in detoxification. Similar pattern was observed by Selladurai et al. (2009) for the treatment of tannery sludge using the same species E. eugeniae and E. fetida.

The micronutrients like iron concentration was $1.22 \mathrm{ppm}$ in control and $19.64 \mathrm{ppm}$ in treated water hyacinth waste and manganese also showed same pattern (1.92ppm in control and 5.94ppm in treated). However among the two micro nutrients the increase amount was observed when compared to manganese in the combinations with both species. When compared with the initial levels, concentrations of heavy metals viz $\mathrm{Zn}, \mathrm{Fe}, \mathrm{Cu}, \mathrm{Pb}, \mathrm{Mn}$, $\mathrm{Cr}, \mathrm{Na}$ and $\mathrm{Co}$ have a significant decrease in their respective values when municipal sludge treated with $E$. eugeniae (Selladurai and Anbusaravanan, 2009).
Plant growth studies the combination of water hyacinth treated with two species of earthworms (E. eugeniae and $E$. feti da) showed maximum growth of root length $(8.9 \mathrm{~cm})$ and shoot length $(21.6 \mathrm{~cm})$ in $\mathrm{E}: \mathrm{S}: \mathrm{C}$ combination of $1: 1: 2$, treated with Eudrilus eugeniae. The root length $8.5 \mathrm{~cm}$ and shoot length $21.3 \mathrm{~cm}$ was observed in combination of 1:2:1 treated with E isenia fetida. (Table 2). Ranuga et al. (2009) reported that the dye sludge vermicompost was used in plant cultivation and results confirmed that plant growth were healthy in $125 \%, 100 \%, 75 \%$ but in $50 \%$ and $25 \%$ vermicompost used cultivation pot plant growth was not appreciable.

Microbial analysis in the earthworms collected from the 1:2:1 and 1:1:2 combinations showed that Bacillus cereus and Micrococcus luteus were dominant in the gut analysis of E. eugeniae and E. fetida treated with water hyacinth. Selladurai and Anbusaravanan (2009) also observed the same microbes in gut analysis. The interesting finding of the present study in the change of diversity of the microbes in the gut region of earthworms. There was a synergetic relationship between in the earthworm and gut micro flora enhanced 
the release of nutrient available for the plant growth and also become soil conditioner.

\section{Conclusion}

The present study concluded that the E. eugeniae and E. fetida were used to convert Eichornia into vermincompost. Through vermitechnology large amount of Eichornia were converted into organic manure, which is turn not only reduced pollution but also enhanced plant growth. It was very clear that the ratios of 1:2:1 and 1:1:2 (E.S.C) increased length of the root and shoot in lady's finger. It is interesting to study the increasing microbial dynamics, which transporting the waste into vermicompost, traveling through the region of the gut. E. eugeniae and E. fetida were more effective by converting the environmental waste into vermicompost.

\section{REFERENCES}

Corwin, D.L. and Lesch, S.M. (2003). Therory, principles, and guidelines: Application of soil electrical conductivity to precision agriculture. Agronomy J ournal, 95: 455-471.

Dominguez, J. (2004). State of the art and new perspectives on vermicomposting research. In: Edwards, CA. (Ed.), Earthworm Ecology, second ed. CRC Press, pp.401-424.

Edwards, C.A. and Burrows, I., (1988). The potential of earthworms composts as plant growth media; In C.A. Edward and E.F. Neuhauser (Eds.) 'Earthworms in Waste and Environmental Management'; SPB Academic Publishing, The Hague, The Netherlands; ISBN 90-5103-017-7; pp. 21-32.

Jackson, M.L. (1975). Soil chemical analysis. Prentice Hall of India, New Delhi.

Gajalakshmi, S., Ramasamy, E.V. and Appasi, S.A., (2001). Potential of two epigeic and two anecic earthworm species in vermicomposting of water hyacinth. Bioresource Technology, 76: 177-181.

Gajalakshmi, S., Ramasamy, E.V. and Appasi, S.A. (2002). Vermicomposting of different forms of water hyacinth by the earthworm Eudrilus eugeniae Kinberg. Bioresource Technology, 82: 165-169.
Gajalakshmi, S. and Appasi, S.A. (2002). Effect of application of water hyacinth compost/vermicompost on the growth and flowering of Crosandra undulaefolia and on several vegetables. Bioresource Technology, 85: 197-199.

Gupta, R., Mutiyar, P.K. and Rawat, N.K. (2007). Development of a water hyacinth based vermireactor using an epigeic earthworm Eisenia fetida. Bioresource Technology, 98: 2605-2610.

Olsen, S.R., Cole,C.V., Watanabe, F.S. and Dean, L.A. (1954). Estimation of available phosphorus in soils by extraction with sodium bicarbonate. Circulation of US Department of Agriculture, 939.

Ranuga, D., Anbusaravanan, N. and Krishnamoorthy, R. (2009). Study on dyeing waste management through vermicomposting. Pro. Nat. Seminar on Enviro.Biore. Tech., 18

Selladurai G and Anbusaravanan N. (2009). Microbial Diversity and Nutrient analysis of Tannery Sludge treated using earthworms. J ournal of E cotoxicology and E nvironmental Monitoring, 19(6): 577-583.

Selladurai G., Anbusaravanan N., Prakash Shyam K., Palanivel K. and Kadalmani B., (2009). Biomanagement of municipal sludge using epigenic earthworms Eudrilus eugeniae and Eisenia fetida. Advances in Environmental Biology, 3(3): 278-284.

Simard, R.R. (1993). Ammonium acetate extractable elements In: Soil sampling and methods of analysis. Eds: Martin.R and Carter.S. Lewis publisher FL USA p.39-43.

Sinha, R.K., Bharambe, G. and Ryan, D. (2008). Converting wasteland into wonderland by earthworms: a low-cost nature's technology for soil remediation: a case study of vermiremediation of PAH contaminated soil. The Environmentalist, 28: 466-475.

Suthar, S. (2007). Bioconversion of post harvest crop residues and cattle shed manure into value-added products using earthworms Eudrilus eugeniae. Ecology Engineering, 32: 206-214.

Walkley, A. and Black, I.A. (1934). An examination of the degtjareff method for determining soil organic matter and prepared modification of the chronic acid titration method. Soil Science, 34: 29-38. 